\title{
The Justice of the Peace System in the United States*
}

I.

\section{Defects of THE System}

$\mathrm{L}$ ITTLE did King Edward III imagine, when he called into existence the justice of the peace system in the early part of the fourteenth century, that he was creating an institution which was destined to persist tenaciously in our jurisprudence for centuries. But that is exactly what has happened. The system has continued in England to the present day. The British colonists brought the institution to America with them. It was an important factor in the colonies and is now a part of the judicial machinery in all the states of the Union. Nor is it to be doubted that it: filled a need in the backwoods communities of the distant colonial days when means of travel and communication were slow and difficult and often impossible. Then, it was necessary "to decentralize the administration of justice so as to bring justice to every man in a sparsely settled community." 1 A court was needed in every hittle hamlet, few lawyers were available and there was little confidence in those who were at hand. ${ }^{2}$ As in a primitive society, the problem was to settle disputes among neighbors and to prevent friction where possible. In short, it was "to keep the peace." 3 Without question in such a social organization the justice was worthy of his hire. Few legal principles or rules had been worked out and there was little legislation either to guide or hamper the magistrate. Hence, he was probably as capable as anyone to administer justice according to his own judgment and common sense. But today with paved roads, automobiles and instant communication, all of which obtain, with but few exceptions, in the remotest rural communities, it is safe to say that the conditions which forced the creation and spread of the justice of the peace system in the United States have long since ceased to exist. We

*The writer acknowledges his indebtedness to Dean Roscoe Pound and Professor Austin W. Scott of the Harvard Law School.

* 1 Pound, The Administration of Justice in the Modern City, 26 Harvard Law Review, 302, 307.

2 Harley, Ultimate Types of Inferior Courts and Judges, 22 Case and Commerit, 3.

3 Pound, The End of Law, 27 Harvard Law Review, 195, 198.

1 See supra, n. 2. 
live in a complex commercial and industrial age which has developed a highly technical and specialized body of legal precepts and enactments peculiar only to a period of maturity of law. ${ }^{5}$ The justice of. the peace is called on to make application of these laws. It follows that the justice of the peace of today is a judicial officer ${ }^{6}$ having jurisdiction over a great variety of crimes and civil causes and who, to exercise such jurisdiction properly and fairly, must be able to apply judicially a great multitude of laws. The result is that in no slight degree the liberty, security and property of the citizens rest with the justice, so that just in the degree that he is capable to fulfill his mission as a judicial officer has he any claim to continue as such.

Chancellor Kent says, "Personal security and private property rest entirely upon the wisdom, the stability and integrity of the courts of justice." It seems to me that that statement sets forth a standard by which we may fairly judge the fituess of members of the bench in any system of courts. Let us apply it to the justice of the peace system and determine, by the integrity, wisdom and stability of its judges, the claim which it may have to continue as a part of the judicial system in the states of the Union. It may be objected that Chancellor Kent was speaking of courts of record or superior courts, and that the statement as made has no reference to inferior courts. Such an objection might have been considered well taken in the beginning of the nineteenth century when the principal aim of the law was the formulation of legal precepts as ends in and of themselves and when little attention was paid to justice in the particular case inter partes, and particularly when small causes were given almost no consideration if not wholly ignored. But the legal profession of today knows no such objection. Our viewpoint has changed. As never before the "poor litigant" with his "petty cause" is being recognized as not an object of charity or sympathy but one whose claim as asserted must be taken cognizance of by the law, one who has a right to have his cause heard according. to the same standard of justice and by a tribunal with as high a degree of training as the man with a lawsuit involving thousands or millions of dollars. The suggested test is a good one; and though

- See Pound, Outlines of Lectures on Jurisprudence (3rd ed.) pp. 40-43. In his lectures on jurisprudence at Harvard University 1923-24 Dean Pound often stated that we are now at the end of a period of maturity of law or are entering on another stage which he terms the Socialization of Law.

- State v. Port (Cir. Ct. Ga. 1880) 3 Fed. 117, 123; Scott v. Spiegel (1896) 67 Conn. 349, 35 Atl. 262; Tissier v. Rhein (1889) 130 IIl, 110, 22 N. E. 848; Webster v. Boyer (1916) 81 Ore. 485, 159 Pac. 1166.

71 Kent's Commentaries (14th ed.) p. 356. 
perhaps well taken at an early period of our history, the objection has no application today and should be ignored. There is no basis in logic or reason for requiring a different standard of qualifications for the officer deciding disputes between two citizens having large sums in contrcversy and the officer determining disputes between two citizens havingr but a few dollars in controversy. This topic will be treated more fully later. Let us now turn to the influences which may serve to unclermine the integrity of the justices of the peace as part of the systen we are discussing.

First, we must remember that the justice is essentially a fee-paid judicial officer. ${ }^{8}$ In other words, he receives his compensation from the very litigants who bring cases before him or from the defendant who is summoned into court by the justice at the instance of the plaintiff. No one who has had any experience in the world of affairs needs to be told that if a man's own financial status is involved in a controversy, he is hardly an unbiased judge. And the legislatures constantly recognize this fact. Otherwise why have they provided in the various statutes since as early as 1792 that a judge or a justice of the peace shall not act as attorney or be counsel for litigants in his own court, ${ }^{9}$ or that he be prohibited from suing for the collection of claims in his own court, ${ }^{10}$ or forbidden from becoming a collector, ${ }^{11}$ from occupying offices with lawyers, ${ }^{12}$ or from practicing law ?13 These prohibitions may appear too obvious to mention, but on principle it does not seem any clearer that the assumption of any such roles would have the effect of influencing his decisions any more than the fact that he may be able to get his fees and costs from one party and not from the other. Yet the justice of the peace has been from the earliest time and still is permitted to determine controversies when he knows that if he decides the case one way he will be paid his statutory fees and if he decides it the other way, he will fail to receive his fees. What could be a plainer case of direct financial interest of the judge in the case hefore him for decision? This is the exact situation which led Mr. Reginald

8 In forty-four states the justices receive fees as remuneration for their services in cases over which they preside as judicial officers or committing magistrates or for administrative duties performed; in Louisiana and South Carolina they receive fees in civil cases and salaries in lieu of fees in criminal cases; in California and Florida the fee system has disappeared and the justices receive only salaries.

9 Kan. Gen. Stats. (1915) § 3734; Me. Rev. Stats. (1916) ch. 88 § 32, 33;

N. H. Const. (1792) \& LXXIX.

10 Wis. Stats. (1921) \& 4509a.

11 Del. Rev. Code (1915) \& 3960.

12 Okla. Comp. Stats. (1921) \& 1692.

13 Mont. Rev. Code (1921) § 8869; N. C. Cons. Stats. (1919) § 198. 
Heber Smith in his very valuable work, "Justice and the Poor," to utter the following, "The justices, being subject to no supervision, and depending so much on their fees that J. P. came to mean 'Judgment for the Plaintiff,' formed unholy alliances with collection agencies, installment houses, and the like, and very generally became actually corrupt." It It is self-evident that in such a system the justice's "dependence on fees tends powerfully to undermine his integrity."

It is interesting to note in this connection that in the colonies some, if not all, of the superior courts at one time or another received their compensation in the form of fees. ${ }^{15}$ But the fee system seems to have been long since abolished in courts other than those of the justices of the peace. ${ }^{16}$ Nor do we hesitate to aver that such a system would act as a powerful deterrent to keep men of ability and sterling qualities from assuming the duties of an officer who necessarily depends on fees for his compensation. What conscientious and capable man is going to occupy the bench of a court if a consideration of the financial status of the litigants must enter into the case? What manner of man is it in this day and age whose integrity is beyond question, who is willing to spend his time in adjusting disputes between parties where the amount is small, simply for the public welfare without regard to the emoluments of office? We do not argue that there are not such men, but we do venture to assert that they are few and that any system depending on finding them ever at hand is plainly Utopian. ${ }^{17}$

Second, we must not lose sight of the fact that the justice of the peace is generally elected by the people of the district in which he serves. $^{18}$ This means that he is not beyond local attacks and the

14 Op. cit., p. 42.

25 Even the Chief Justices in the Colony of Georgia received fees for their services. Colonial Acts (1755-1774) p. 344. See also the statutes of other colonies.

10 "No judicial officer, except Justices of the Peace, shall receive to his own use, any fees or perquisites of the office." N. Y. Const. (1846) Art. VI $\$ 20$ and amendment thereto (1876) Art. V \& $21 ; \dot{N}$. Y. Const. (1894) Art. VI $\S 20$; Nev. Const. (1864) Art. VI $\$ 10$.

17 "It is requisite that the courts of justice should be able, at all times, to present a determined countenance against all licentious acts; and to deal impartially and truly, according to law, between suitors of every description, whether the cause, the question or the party be popular or unpopular. To give them the courage and the firmness to do it, the judges ought to be confident of the security of their salaries and station." 1 Kent's Commentaries (14th ed.) p. 359.

${ }^{18} \mathrm{An}$ examiuation of the statutes and constitutions discloses that in fortyone states the justices are elected; in six states they are appointed by the governor by and with the consent of the council or senate; in Rhode Island they are elected in the towns but the governor with the advice and consent 
influence of petty politics. His integrity as a judicial officer is inevitably affected by his desire to continue in office and this dependis on his ability to poll votes. It cannot be gainsaid that the justice is not an unprejudiced arbiter when he has before him a party litigant who is his friend and who is able to control a respectable number of votes. But oftentimes a more powerful politician than a party litigant appears in the justice court who is also interested in the decision to be rendered, namely, an attorney for one of the parties. Can anyone doubt the effect of such appearance on the judgment in the case? ${ }^{19}$

Then there is another influence which is probably not so apparent, yet which is no less potent than these. When a case comes before a justice of the peace, the decision in which may affect his social status or position in his community, the justice immediately begins balancirg, not the interests involved in the case from the standpoint of the parties, but his own interests with those to be affected by an adverse adjudication. This may be brought about by the position of one of the parties in the social or religious life of the locality or from the popular feeling about the issues involved in the particular case at hand. We often see that the social prestige of a man and his family is a great factor in determining his activities and judgments.

While there are, perhaps, many other influences tending to break down the integrity of the justices of the peace as such, we believe those just mentioned are sufficient to instil a complete lack of confidence in and respect for the system.

But may it not be that the wisdom of the justices is such that it successfully combats the effect of these other influences? Let us see. Reference to the statutes of the states gives us no aid here for, with the exception of Louisiana, ${ }^{20}$ which merely requires that the

of the General Assembly may, if he deem it necessary, appoint other additional justices.

19 Mr. C. B. Griffith, Attorney General of Kansas, in a letter to the writer dated January 4, 1924 writes, "The worst trouble about Justices of the Peace, however, is that so many times some man is elected who does not hold himself aloof from being misled by some unscrupulous lawyer."

This defect, no doubt, is what caused a leading attorney of South Dakota to remark in the writer's presence, "Every lawyer has his justice of the peace."

${ }^{20} \mathrm{La}$. Const. (1921) Art. VII \& 47.

"While careful to incorporate the office in the Constitutions of many of the states, our ancestors were strangely silent on the question of the qualifications of persons to be elected thereto." Strasburger, A Plea for the Reform of the Inferior Court, 22 Case and Comment, 20. We here refer to the justice of the peace as provided for in the constitutions of the various states and under statutory provisions relating to justices throughout an entire state and not to justices established under special statutes in certain cities or localities. 
justice be able to read and write the English language correctly, they require no qualifications so far as learning is concerned. Then it seems that the only way to determine this question is to approach the matter from the standpoint of actual practice. How does the system function, and what are the qualifications of the men who are actually acting as justices of the peace? In determining their wisdom we assume without argument that the term here means capacity for the particular work in which they are engaged as judicial officers. A man may be a wizard in other fields but may display no sign of his genius when acting as a judge. Again, there may be and there are men in the justices' positions who show rare tact and skill in deciding cases and who administer justice with a fair degree of satisfaction but this fact in itself does not justify the system as a system. In general I should say that there are four classes of men whom we find acting in the capacity of justices of the peace. First, those who are intelligent, conscientious and possessed of courage and strong moral character; second, those who are intelligent but who are entirely lacking in moral fiber; third, those who are prompted by the highest desire to do what is morally right but who are wholly ignorant and inexperienced; and fourth, those who are both ignorant and unprincipled. As we have indicated, if all of the justices were of the first class we would perhaps hear little criticism of the administration of justice in the justice of the peace courts and there would be confidence in and respect for the institution. There would be little hesitation to permit courts with such qualifications to decide questions involving personal liberty and property. But even then many would hesitate to submit the interpretation of law and statutes to such a court. It would be but a wild speculation to estimate the percentage of justices of the peace who should be grouped in this first class, but to any who have had much experience with this kind of court, it would seem the percentage would be small indeed.21 In

In Idaho it seems sufficient if the candidate for justice of the peace is a resident of the precinct; in Kansas an elector of the township; in Georgia a resident and elector of the district; in Virginia and Nevada a qualified voter. In Mississippi he must be a resident of the district from which he is chosen for two years prior to his election and in Montana a citizen of the United States and a resident of the county for one year before his election. In Kentucky he must be twenty-one years of age, a resident and elector from his district and a citizen of the United States. But in Illinois the justices must be "fit and competent".

In many states, unless covered by some general provision, there seems to be no specific reference to the justices' qualifications.

21 "The occasional capable justice cannot offset the prevalent Dogberry type." Harley, Efficient Local Courts, 3 Journal of American Judicature Society, 13, 14. 
the other three classes mentioned we find either ignorance, inexperience, or lack of moral fiber and principle or all of these combined. Can anyone wonder why there is lack of confidence in and respect for a system of courts manned by individuals whose wisdom is so crippled? "This deplorable condition is not the result of the evil machinations of any group or class; it is the consequence of the failure of the judicial system to keep pace with the changing conditions of life."22 When we have a highly technical and specialized body of law by means of which and through which we demand that justice be admimistered, what confidence in our judicial organization can we hope to develop when we elevate farmers, blacksmiths, carpenters, shoemakers, ${ }^{23}$ plumbers and every conceivable kind of laborer and tradesman to the bench of a court of justice? It is as inconsistent to assume that a layman can administer law correctly as it is to assume that a litigant should go to a blacksmith to have his dental work done ${ }^{24}$ or to a farmer to have a cost accounting problen in manufacturing worked out.

Mr. S. F. Davis has vividly portrayed the attitude of such justices. He says that although the constitutions and statutes fix the jurisdiction and territorial limitations of and prescribe rules of procedure in the justice of the peace court as well as define its duties, "All this is conveniently ignored by some justices of the peace, who never allow themselves to be hampered, or their jurisdiction or court procedure restricted by any rules or regulations by the legislature or anybody else." "They exercise original and unlimited jurisdiction over all such things as are given them by the statutes, and they assume concurrent jurisdiction over everything else that they find

22 Srnith, Justice and the Poor, p. 42.

23 Dizan Pound tells an interesting story illustrative of the point at hand. He says that in his home state a certain pettifogger was raised from the shoernaker's bench to the hench of justice of the peace. This promotion very much affected his equilibrium and when he got into an argument with a group of his fellows on the street and was getting the worst of the argument, he at once sought shelter behind the authority of his newly acquired position. $\mathrm{He}$ went directly to his office and prepared contempt papers against his rival in the argument. Some of the friends of the villain who had been so indiscreet and disrespectful as to argue with "THE JUSTICE OF THE PEACE" went to the justice and told him that he could not have his adversary arrested for contempt, whereupon the dignified justice stretched himself to his utmost height and exclaimed, "I want you to understand that I am a Justice of the Peace and as such am always an object of contempt."

24 Mr. T. R. Gress, Assistant Attorney General of Georgia, in a letter to the writer dated Dec. 7, 1923, writes as follows, "On another occasion I attended a rural court, arriving about an hour before court was to convene. I called at the home of the Justice of tbe Peace and found him engaged in shoeing at steer."

25 Something about Some of the Justices' Courts of Mississippi, 22 Case and Comment, 42. 
loose in their districts." "They all have and exercise the right to hold their courts at any place in their district, but usually select a country store or postoffice as the place most suited for this business. They generally like to have their trials well attended, and so hold their court where it is most likely to draw the largest crowd, so that their judicial light will shine to the best advantage."2r Though these statements may seem hyperbolical to some, they will not so appear to those who have had actual contact with the justice court. They do not exaggerate in the least some of the characteristics of the system which have come under the observation of the writer. These characteristics bring this system of courts into popular disrepute, and cause all manner of charges to be brought against it. ${ }^{28}$

This attitude presents a phase of our topic which seems to have been discussed but to a limited degree in the books, and then in a very general manner. Naturally enough, since few justice courts are courts of record, we learn little from the reports about what actually takes place there. Again probably a very small percentage of cases are appealed from the justice court for no other reason than that the amount involved will not warrant the increased expenditure. But one case in the reports seems to describe vividly both the position of the justice of the peace and the functioning of his court. For this reason I do not hesitate to quote in full Mr. Justice Blandford's statement of it.

"No appearance for defendant.

"This case was tried in a justice's court on appeal before a jury, the Honorable R. G. Riggins, justice of the peace, presiding. His Honor charged the jury as follows: 'Gentlemen, this is a case which has been tried by me before, and I decided in favor of defendant; I further charge you, gentlemen, that if you find that any settlement has been made, you find for defendant; retire and make up your verdict.'

"The law does not require a justice of the peace to charge the jury at all; his ignorance of the law, as well as propriety, would seem to demand that he should not, but if he under-

26 Ibid., p. 43.

27 Ibid., p. 43.

${ }^{28} \mathrm{Mr}$. W. T. Waters writes as follows: "The justice courts were charged monotonously and wearisomely with accepting straw bonds; with connivance between court officials and litigants; with using criminal machinery for the collection of debts; with having people jailed at night without bond who might easily have been arrested in daylight hours; with rough handling of prisoners; and with the issuance of garnishments against persons whose wages were known to be exempt. In short, as the Fulton grand jury of the March term, 1911, summarized it, they were charged with conduct which, 'tends toward anarchy and brings into disrespect and disrepute the laws of the land!" Atlanta's New Municipal Court, 78 Central Law Journal, $147,150$. 
takes to instruct the jury, he must do it correctly and in accordance with law. A justice of the peace is generally a man of consequence in his neighborhood; he writes the wills, draws the deeds and pulls the teeth of the people; also he performs clivers surgical operations on the animals of his neighbors. The justice has played his part on the busy stage of life from the time of Mr. Justice Shallow down to the time of Mr. Justice Riggins. Who has not seen the gaping listening crowd assembled around his honor, the justice, on tiptoe to catch the words of wisdom as they fell from his venerated lips?

"And still they gazed,

And still the wonder grew,

That one small head

Could carry all he knew!'

"The instructions given in this case exercised an undue and unwarranted influence upon the jury. Such is to be inferred from the fact that they found for the defendant, when the evidence was overwhelmingly in favor of the plaintiff. The judge of the superior court should have granted the writ of certiorari in this case, and it was error to have refused the same.

"Judgment reversed."

This case reveals a part of our judicial system in action. Among the last three classes of justices named above it is seldom that we do not: find the "court" consumed in his own wisdom. ${ }^{20} \mathrm{He}$ is often not orly wholly uncontrolled by the law but is a law unto himself..$^{30}$ We therefore conclude on this point that the wisdom of the men who actually preside over our justice of the peace courts is not such as we believe Chancellor Kent meant to be required of a court of justice.

The next question to be solved is whether these courts possess the stability which is deemed requisite to a judicial tribunal. Here

20 Bendheim Bros. \& Co. v. Baldwin (1884) $73 \mathrm{Ga} .594$.

$30 \mathrm{MMr}$. H. S. Farris relates an instance where a justice of the peace in Alaska in absolute violation of the statutes established a whipping post where Indians; were flogged. When asked whether the statutes permitted such practice he exclaimed, "To hell with the statutes, what I want to do is to stop these siwashes from drinking hootch!" Another justice made prisoners serve cut their sentences at the rate of one dollar per day instead of two dollars per day as provided by statute. Alaska's Inferior Court, 22 Case and Comment, 16.

Mr. S. F. Davis writes of a justice of Mississippi causing a negro to be bound up with rope for "jumping a contract" and at the trial, he being counsel for the defendant, objected to an examination of the negro and read to the justice the United States and state constitutional provisions, protecting a prisoner charged with a crime from testifying against himself. To this the justice replied, "To hell with the Constitutions, they don't have no bearing in this court, and I'm going to hear what that nigger has to say about this case, or know the reason why." Something about Some of the Justices' Courts of Mississippi, 22 Case and Comment, 42, 45.

Mr. J. S. Utley, Attorney General of Arkansas, in a letter to the writer dated December 7,1923 , writes as follows: "A justice of the peace in Saline 
we assume the term stability to mean the consistency with which the court administers justice according to law. ${ }^{31}$ We have before called attention to the fact that the justices of the peace are laymen, that they are not required to be otherwise, and that they are very seldom "learned in the law." If we are right in this assumption, our problem resolves itself into one of the following propositions, to wit: Our statutes dealing with the justice of the peace system postulate a justice according to law, that is, justice through the application of legal rules, standards and principles, which justice is to be administered by a tribunal which for the most part is wholly unlearned in the law. This proposition seems to be almost a contradiction. $^{32}$ On the other hand, if our statutes do not postulate a justice according to law they must postulate a justice without law, thus making the justice of the peace system equally assailable as being part of an archaic judicial system which has clung tenaciously to its old form without change or revision, wholly failing to keep pace with the changing conditions of our social and economic life..$^{33}$ And the effect of this static system in a changing environment has been aggravated by the fact that legislatures have continually enlarged the jurisdiction of its courts.

We have already seen that the wisdom and common sense of the justices were not a sufficient deterrent to keep them within the provisions of the laws giving them limited authority and protecting the rights of citizens against their usurpation of power. But what of the uniformity of their decisions? With no training in the law, no training in the process of judicial thought, no mental habit of mind which is acquired only by constant experience in legal reasoning, it would indeed be strange if a justice of the peace did not treat each case as a unique proposition. He has no category or class into

County declined to permit the attorney in an attachment suit to read a decision of the State Supreme Court in support of a motion to dismiss the attachment, 'because', said the justice of the peace, 'opinions don't go in this court'."

He continues, "A justice of the peace in Hot Spring County, having shown his hostility toward one side of a case, the attorney for that side, during a recess of the court, left and did not return. Several months after when the transcript came to the circuit court on appeal it contained a judgment for contempt of court against the attorney who had thus left, this being the first notice the attorney had of the contempt proceedings."

31 See Pound, Justice According to Law, 13 Columbia Law Review, 696, 14 Columbia Law Review, 1, 103.

32 "All that the judge absolutely requires is authority to settle all disputes which come before him. .... A tribunal altogether without law, though scarcely withiu our experience, is not a contradiction." Markby, Elements of Law (6th ed.) p. 112.

33 See Pound, Some Principles of Procedural Reform, 4 Illiuois Law Review, 388, 491; The Administratiou of Justice in a Modern City, 26 Harvard Law Review, 302; Smith, Justice aud the Poor, p. 42. 
which he may place it, no analogies from which to draw to solve the new problem before him. He has no legal rules, principles or stanclards by which to judge the merits of the controversy to be decided. Wholly unlike the judge who is trained in the law, he has no precedents to guide him. In deciding the cause before him, the justice is necessarily limited by his own personal experience acquired in the short span of a single lifetime. He cannot call on the legal experience of the ages to assist him but is helpless to do any more than apply his own personal notions of right and wrong to the case at hand. The justice which such a tribunal is capable of dispensing is but the outcropping of the experiences of a personality, often limited and warped by passion and prejudice, and at best, as variable as the personalities of the justices who comprise the justice of the peace system. "Wise beyond his fellows was the suitor who could guess what the same court would hold at its next sitting." Such justice is not justice at all. It is "unequal, uncertain, and capricious." 35 While we realize that certainty in the law is an illusion ${ }^{36}$ when we view the law through the eyes of the jurist as an ever evolving phenomenon, ${ }^{37}$ yet we do not hesitate to aver that there is a degree of certainty in the treatment of cases in courts other than justice of the peace courts on which litigants should be able to rely with confidence. The advantage of this certainty is given the man with a case involving large sums but is utterly denied the man with a case involving a sum over which the justice of the peace has jurisdiction. The latter must speculate on (1) the feeling of the justice towards his cause, (2) the political status of his adversary or his counsel, (3) the financial standing of his opponent, (4) the social. position of the other party, (5) the possibility of an adverse judgment even though the substantive law is well settled in his favor, and $(6)$ the risk of expenses incurred with a possible "barren victory"3s on appeal. The lay judge does not have the ideals, habits, thinking or professional technique necessary to the administration of justice and the deciding of cases according to the substantive common law. His decisions know no equality, certainty or uniformity. Like the lay judges of New Hampshire, the "whole pro-

34 Corning, The Highest Courts of Law in New Hampshire, 2 Green Bag, 470 .

${ }_{35}$ Pound, Outlines of Lectures on Jurisprudence (3rd ed.) p. 75.

36 "But the certainty is only an illusion, nevertheless." Holmes, Privilege, Malice and Intent, 8 Harvard Law Review, 1.

${ }^{37}$ As Dean Pound is wont to put it, "the law that is, isn't."

${ }^{38}$ Scott, Small Causes and Poor Litigants, 9 American Bar Association Journal, 457. 
cess [savors] too much of a lottery, where luck, and not reason, [wins] the prize."39 Nothing is clearer than the fact that neither the justices of the peace nor their decisions have stability.

Then we conclude that the courts of the justice of the peace system, as such, possess none of the qualities which the great American Commentator considered requisites of a court of justice, to wit: integrity, wisdom and stability.

While it was the principal object of this part of this paper to set forth the defects of the justice of the peace system as reflected through the justices themselves, yet there are certain other defects so glaring that I cannot pass them without mention. The inefficiency and waste of such an organization has received exhaustive treatment elsewhere, ${ }^{40}$ but we especially call attention to the fact that the statutes of the states, with but few exceptions, ${ }^{41}$ provide that the justice of the peace court is not a court of record and that the trial on appeal therefrom shall be de novo. Such provisions recognize the weakness of the system and reduce the trial in the justice court to a mere sham causing such delay and expense as to be a virtual denial of justice.

30 Speaking of lay judges Mr. Corning says, "It does not appear that the people held the judges in lofty veneration, for the whole process of justice savored too much of a lottery, where luck and not reason, won the prize. Law learning was not a requisite for judges till long after the Revolution; and it came to pass that almost anybody except a lawyer was thought of as the proper person to sit on the bench. Laymen were repeatedly appointed, and this practice continued with general approval until judicial affairs soon became nothing more than a bundle of wrongs and grievances bound up in faded red tape." The Highest Courts of Law in New Hampshire, 2 Green Bag, 470.

It seems to me that that statement is applicable to the justice of the peace system which has continued principally because the profession and the legislators have had little interest therein. There have been few leaders among those aggrieved and wronged by the system and it has waited for the present social awakening to make us cognizant of the shortcomings of the system with its concomitant evils.

40 See Smith, Justice and the Poor; First Report of the Municipal Court of Chicago (1906-7); Pound, The Admmistration of Justice in the Modern City, 26 Harvard Law Review, 302, and Some Principles of Procedural Reform, 4 Illinois Law Review, 388, 491; Scott, Small Causes and Poor Litigants, supra, n. 38; Proceedings of Commission to Inquire into Courts of Inferior Criminal Jurisdiction in Cities of the First Class Vol. I to V (1909) (N. Y.).

41 Burn's Ind. Stats. Anno. (1914) § 1725; Carroll's Ky. Stats. (1922) § 1088; Md. Const. (1867) Art. IV, Part I, \$ 1 .

"A court held by a justice of the peace is in this state a court of record. His record, therefore, of any judicial proceedings which have taken place before him, and were within his jurisdiction, imports verity, and its statements cannot be collaterally questioned. Every fact recited in such a record is presumed to have been properly and rightly done, until the contrary appears." American Bonding Co. v. Hoyt (1914) 88 Conn. 251, 90 Atl. 932; Church v. Pearne (1902) 75 Conn. 350, 351, 53 Atl. 955. See also Fitch v. Byall (1898) 149 Ind. 554,49 N. E. 455. 
So while we fully agree with Mr. George W. Woodruff, Attorney General of Pennsylvania, who asserts that "Justices of the peace, being elective officers, and not necessarily having any legal training, range all the way from the highest type of help to the public good to those who are merely a blot on the good name of the State,"12 yet we may say of the system: first, the judges, being dependent on popular local vote for their offices and on the fee system for their compensation, are subjected to local political, social, and religious influences and to an ever present personal financial interest in the litigation before them, all of which not only produce biased and prejudiced decisions but gnaw away the very integrity of the courts and lead to corruption; second, the judges are often not only unintelligent but unprincipled and wholly uncontrolled by statute or constitution, all of which reduces the administration of justice to the caprice of a dictator consumed in his own wisdom; third, the judges being wholly untrained in the law have not the ability to decide legal controversies according to the substantive law, and this deficiency inevitably makes their judgments unequal, uncertain, and unstable-the creation of chance and speculation; fourth, instead of being a "bureau of justice," 43 it denies justice and is perhaps more often a "bureau of injustice"; and fifth, it is an antiquated part of our judicial machinery.

Is it not ludicrous for the legislators to assume to control the mental habit of a man whose intelligence and training are often so infer:or that he is unable to read or understand the very provisions of the laws through which it is sought to restrain him? Is it a recognition of our social and governmental weakness or of legislative: blundering that we legally recognize and delimit de facto claims of our citizens and fail to provide competent tribunals to secure them? What could be a plainer contradiction than for the state to tell a man that he has a right and fail to provide an institution to give it legal effect? The answer probably is that the justice of the peace has been and is a politician of no mean standing in his community.

II.

\section{Importance of the Justice of the Peace System}

The significance of the subject under discussion may not appear at first glance but it is of signal importance. Just as the life of the

42 From a private letter to the writer dated January 2, 1924.

43 Pound, The Administration of Justice in the Modern City, 26 Harvard Law Review, 302, 319. 
law lies in its enforcement, ${ }^{44}$ so the strength of the judiciary lies in the confidence the people have in its judges. It is in the minor courts, and I should say particularly in the justices' courts, that the great mass of our people get their only experience with the machinery of justice. Here is the most frequent point of contact between the citizenry and the judiciary. In fact the justice court is the only court which many of our citizens know, and just in the degree that they are treated well or ill there, just in that degree do they have a wholesome respect for their judicial institutions. From what we have already seen, it is to be lamented that these tribunals, which seem to be the worn-out $\operatorname{cog}$ in the wheel of our judicial machinery, should be the medium through which our courts have their greatest political influence and by which they are judged.

We cannot estimate too highly the value of competent inferior courts. "Judges who can handle the commoner causes with tact and dignity are not plentiful." 45 They are invaluable. They alone can create the necessary respect for our judiciary. Any element in our judicial system which causes disrespect for the law or our institutions should meet with hearty disapprobation and condemnation. If higher salaries are necessary to secure the services of honest, capable, and law-trained judges to administer justice in our minor courts it is false economy not to grant them. "Economy lies in getting a right and lasting adjudication in the first instance, and this requires exceptional men." 46 "It is the duty of the state to afford every litigant, without regard to the amount involved in his controversy, the opportunity to secure a determination thereof according to the highest conception of justice." 47

III.

\section{The Recent Tendency}

Recently some states have attempted to fulfill this duty. But this tendency seems to be limited to certain districts, cities or portions of the states. For example, in Oregon while the justices receive fees generally, in certain counties and precincts they are required to

44 As Dean Pound has so often said.

45 Harley, Ultimate Types of Inferior Courts and Judges, 22 Case and Comment, 3,7 .

10 Ibid.

47 Strasburger, A Plea for the Reform of the Inferior Court, 22 Case and Comment, $20,22$. 
account for their fees and receive a salary. ${ }^{48}$ In Washington a like situation obtains in cities or towns having over five thousand inhabitants, ${ }^{49}$ and in Wyoming in precincts of over fifteen hundred population. ${ }^{51}$ In New York the statute provides that in towns of over twenty thousand people the town boards may allow the justices salaries in lieu of fees in criminal cases. ${ }^{51}$ New Hampshire has worked out a rather detailed system of police courts. The state is divided into fifty-two districts. In each district in which the system has been established a police court presides. This court consists of "one learned, able and discreet person appointed and commissioned as justice" by the governor. These are courts of record and it is provided that civil proceedings shall be made returnable before these courts, where established, and not before a justice of the peace. So it seems that while the justice of the peace is relieved of his civil jurisdiction the office still remains. ${ }^{52}$ In Colorado the present tendency seems to be to raise the standard of justice by paying salaries to the justices of the peace in counties having from ten thousand to thirteen thousand inhabitants, ${ }^{63}$ and in counties having one hundred thousand population the tendency seems to be not only to pay a higher salary but to require that the justice of the peace be a lawyer of three years' experience in the practice. ${ }^{54}$ It is interesting to note that in Missouri, in cities of from seventy-five thousand to four hundred thousand population and over, the justices of the peace have civil jurisdiction when the amount in controversy is as high as five hundred dollars and that they are paid salaries ranging from two thousand to three thousand dollars. However, I do not find that any justice in Missouri need have any other qualifications than that he be a citizen of the United States, an inhabitant and resident of the state and city for twelve months next preceding his election.5 California has provided a real organization for her justices of the peace in certain portions of the state. In every city and county of over four hundred thousand population there shall be five justices of the peace elected and they shall elect from their number a presiding officer. Each justice

48 Ore. Laws (1920) \$§ 3579-81, 3591-93.

19 Wash. Const. (1889) Art. IV $\S 10$; Rernington's Comp. Stats. (1922) $\S \S 7571-75$.

50 Wyo. Const. (1889) Art. XIV § 2; Comp. Stats. (1920) § 6456.

51 Cumming \& Gilbert's Cons. Laws of N. Y. (1918) \& 107-a. This statute was held constitutional in People v. Cocks (1916) 173 App. Div. 981, 158 N. Y. Supp. 1024.

$52 \mathrm{~N}$. H. Sess. Laws (1913) ch. 169.

53 Colo. Comp. Laws (1921) \& 7937.

5 \& Ibid. \& 7936 .

ss Mo. Rev. Stats. (1919) \$§ 2916, 2923, 2944, 2950. 
receives a salary of forty-two hundred dollars ${ }^{56}$ and is required to be qualified to practice law in the state. In Virginia, in cities between ten thousand and forty-five thousand population, a "special justice of the peace," to be known as "the civil and police justice," is elected for a term of four years. ${ }^{57}$ He receives a salary ${ }^{58}$ and must have practiced law in the state for at least five years. ${ }^{59}$ While the jurisdiction of this court is practically the same as other justice of the peace courts, ${ }^{60}$ yet in the cities where it is established, other justices of the peace are practically ousted of jurisdiction. ${ }^{61}$ In cities of over forty-five thousand inhabitants a "civil justice," learned in the law and with at least five years' practice in the profession, is elected for a term of six years and has nearly the same jurisdiction as other justices of the peace but where he has such jurisdiction the others are practically ousted except in criminal cases under city ordinances. These justices receive a salary of at least three thousand dollars per annum. ${ }^{62}$

The old justice of the peace system is also losing ground in the cities where municipal courts have been established. ${ }^{63}$ And in New Jersey "no justice of the peace resident within the limits of any city where a district court is or may be established, shall exercise any civil jurisdiction whatever."

However, as we have indicated, these attempted reforms aim at particular localities only. It is an effort to create a better administration of justice where the pressure, due to more diverse and complex living conditions in the crowded areas, is greatest. We are fully aware that reforms in the law move slowly and that it is natural that they should come first where commercial and industrial organization, causing more frequent personal contact and greater variety of conflicting claims of individuals, have made the need felt most. But there are also recent movements which point

56 Cal. Code Civ. Proc. $\$ \S 85,97,103$.

$57 \mathrm{Va}$. Code (1919) § 3097.

58 Ibid. \$ 3100 .

69 Ibid. § 3098 .

60 Ibid. § 3102 .

a Ibid. $\$ 3102$ (b).

62 Ibid. § $3112,3114$.

63 III. Laws (1905) p. 157; City of Chicago v. Reeves (1906) 220 I11. 274, 77 N. E. 237 ; N. Y. Laws of 1897, ch. 378; Irwin v. Street Ry. Co. (1899) 38 App. Div. 253, 57 N. Y. Supp. 253; In re Schultes (1898) 33 App. Div. 524, 54 N. Y. Supp. 34, 103 Ohio Laws (1913) 279, 385; State v. Yeatman (1913) 89 Ohio St. 44, 105 N. E. 74. See also ch. 823 of Acts of Md. (1912) creating the People's Court of Baltimore City and Levin v. Hewes (1912) $118 \mathrm{Md}$. 624, 86 At1. 233, construing the act.

$6 \leq$ N. J. Comp. Stats. (1910) Vol. 3, p. 3018, § 8. 
towards state-wide reforms in the matter we are discussing. This tendency is shown in some of our constitutional provisions and constitutional amendments. ${ }^{.5}$

These recent movements indicate that we are developing the proper attitude towards the lay magistrate, but with respect to our present stage of development they simply indicate that in the large cities and in some smaller cities, litigants having claims involving relatively small amounts have immediate access to courts in which the judges are trained in the law and paid by salary, and who thus dispense judicial justice; that the urban population enjoys that certainty and security in legal transactions which comes only with justice according to law; that in the rural communities of the entire country litigants are still compelled to gamble with the chance caprice of the lay magistrate whose compensation depends on fees; that the rural population is absolutely denied justice according to our highest conception thereof, and is accorded no certainty whatever in legal transactions involving small sums.

Such legislation is a discrimination between urban and rural

65 Neb. Const. (1875) Art. V, § 1; N. D. Const. (1889) Art. IV, § 112; Ohio Const. (1851) Art. IV, \& 1. The development of the recent tendency to make inroads on the justice of the peace system and to empower the state legislature to abolish the system throughout the state is most clearly reflected in the constitutions of Louisiana. The office of the justice of the peace was universal in that state until the adoption of the Constitution of 1879. By that constitution the justice courts were abolished in the city of New Orleans and their places were supplied by City Courts, the judges of which were required to be practicing lawyers of five years' experience preceding their election or appointment. La. Const. (1879) Arts. 125, 135. "The system worked so well that in the Constitution of 1898 a provision was adopted .... reading as follows: "The General Assembly shall have the power to abolish Justices of the Peace Courts in wards containing cities of more than five thousand inhabitants and to create in their stead courts of such civil jurisdiction as is now vested in Justices of the Peace, etc.' and in the constitution of 1913, the same provision was incorporated. Under these provisions about ten such courts have been created." Tlie Constitution of 1921 goes still further and provides, "that the legislature may reduce such number [of justices] or even abolish the office of justice of the peace throughout the state," \$ 46; see also Art. VII, \$ 51 and compare Art. 84 of Const. (1913)

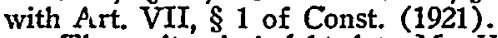

The writer is indebted to $\mathrm{Mr}$. W. O. Hart of the New Orleans bar and a member of the Constitutional Conventions of 1898 and 1913 for most of this information concerning the justice of the peace system in Louisiana. Mr. Hart, in his letter to the writer under date of January 31, 1924, writes, "In the Constitutional Convention of 1921 the question of abolishing Justices of the Peace entirely in the State was considered, but the lobby was too strong and aholishment did not take place."

Mr. Paul A. Sompayrac, Assistant Attorney General of Louisiana, in a letter to the writer under date Dec. 3, 1923, writes, "The question of replacing justices of the peace by judges learned in the law was discussed at length at our Constitutional Convention in 1921. It was urged that as presently constituted, a justice of the peace was a poor man's court, and fulfilled with a great degree of efficiency the needs of rural commmunities." 
populations which no argument can justify and which can be overcome only by state-wide abolition of the office of justice of the peace, and a substitution in its place of a system of minor courts the judges of which have the training which qualifies them to administer justice according to the laws of the land.

IV.

The Problem of State-Wide Abolition of the Justice of the Peace System

We shall now discuss briefly the problem of state-wide abolition of the justice of the peace system. For the purpose of presenting this phase of the subject more clearly $I$ have classified the constitutional provisions concerning justices of the peace with respect to legislative control, first, over the office as such and second, over the jurisdiction which the justice of the peace enjoys.

Those provisions relating to legislative control over the office fall into four distinct types: (A) those which provide expressly that the judicial power shall be vested in the justice of the peace as one of the courts of the state; (B) those which provide that the judicial power of the state shall be vested in such inferior courts as may be established by law, but in which the justice of the peace is not mentioned; $(C)$ those which provide that the judicial power of the state shall be vested in such inferior courts as may be established by law, and in addition thereto further provide that a competent number of justices of the peace shall be appointed or elected; (D) those which provide for the justice of the peace as in classes (A) or (C) supra, but which provide further that the legislature may abolish the office of justice of the peace throughout the state. $^{\text {eb }}$ The constitutional provisions relating to such control

60 Classifying the provisions of constitutions now in force we have the following:

Class (A)-Ariz. (1910) Art. VI, § 1; Ark. (1874) Art. VII, § 1; Del. (1897) Art. IV, \$ 1; Fla. (1885) Art. V, \$ 1; Ga. (1877) Art. VI, § 1; Ida. (1889) Art. V, \$2; III. (1870) Art. VI, \$ 1; Kan. (1859) Art. III, $\$ 1$; Ky. (1891) \$§ 109, 142; Md. (1867) Art. IV, Part I, § 1; Mich. (1908) Art. VII, \$ 1; Minn. (1857) Art. VI, \& 1; Miss. (1890) Art. VI, \$ 144; Mo. (1875) Art. VI, \$\$ 1, 37; Mont. (1889) Art. VIII, § 1; Nev. (1864) Art. VI, § 1; N. Mex. (1911) Art. VI, § 1; N. C. (1876) Art. IV, \& 2; Okla. (1906) Art. VII, § 1; Ore. (1857) Art. VII, § 1; S. D. (1889) Art. V, § 1; Tenn. (1870) Art VI, \$ 1; Tex. (1876), Art. V, § 1; Utah (1895) Art. V, \$1; Va. (1902) Art. VI, \$\$ 87, 108; Wash. (1889) Art. IV, $\$ 1$; W. Va. (1872) Art. VIII, \$ 1; Wis. (1848) Art. VII, \& 2; Wyo. (1889) Art. V, \& 1 .

Class (B)-Cal. (1879) Art. VI, § 1 as amended (1911); Ohio (1851) Art. $\Gamma$, $\S 1$ as amended (1912). 
over the jurisdiction exercised by the justices of the peace may be conveniently placed in three groups: (X) those in which the jurisdiction is specifically set forth, (Y) those in which the legislature may fix the jurisdiction but not to exceed a specified limit which is expressly stated, $(Z)$ those in which the legislature may fix the jurisdiction. ${ }^{67}$

Cliss (C)-Ala. (1901) Art. VI, §§ 139, 168; Col. (1876) Art. VI, § 1 as amended (1912); Conn. (1818) Art V, \$\$ 1, 2; Ia. (1857) Art. V, \$ 1, Art. XI, § 1; Ind. (1851) Art. VII, \$§ 1, 14; Me. (1819) Art. VI, §§ 1, 5; N. H. (1792) as amended (1902)-see Arts. 74, 78; N. Y. (1917) Art. VI, \$ 17; F'a. (1873) Art. V, \$\$ 1, 11; R. I. (1842) Art. X, \$§ 1, 7; S. C. (1895) Art. V, \$\$ 1, 20; Vt. (1793) \$\$ 28, 47.

Class (D)-La. (1921) Art. VII, § 46; Neb. (1875) Art. VI, § 1 as amended (1920); N. J. (1844) Art. VI, $\S 1$ as amended (1875) and (1897); N. D. (1889) Art. IV, $\S \S 85,112$.

There is no provision in the constitution of Massachusetts which dates from 1780 which lends itself to this classification.

87 Classification of these provisions now in force follows:

Classs (X)-Ala. (1901) Art. VI, § 168; Ark (1874) Art. VII, § 40; Fla. (1885) as amended (1896) Art. V, \& 22; Ga. (1877) Art. VI, \& 7, par. 2; Ia. (1857) Art. XI, § 1; La. (1921) Art. VII, \& 48; Miss. (1890) Art. VI, \$ 171; N. M. (1911) Art. VI, \& 26; N. C. (1876) Art. IV, \$ 27; N. D. (1889) Art. IV $\S 112$; Tex. (1876) Art. V, § 19; W. Va. (1872) Art. VIII, \& 28; Wyo. (1889) Art. V, § 22.

Class (Y)-Ariz. (1910) Art. VI, \& 9; Cal. (1879) Art. VI, \& 11; Col. (1876) Art. VI, \& 25; Ida. (1889), Art. V, \& 22; Mich. (1908) Art. VI, \$ 16 ; Minn. (1857) Art. VI, \& 8; Mont. (1889) Art. VIII, \& 20; Neb. (1875) Art. V.L, § 18; Nev. (1864) Art. VI, \& 8; N. H. (1792) as amended (1902) Art. 76; S. C. (1895) Art. V, \& 21; S. D. (1889) Art. V, § 22; Utah (1895) Art. V.III, $\S 8$ and Act to Establish Territorial Government of Utah (1850) \&9.

Class (Z)-Conn. (1818) Art. V, § 2; Del. (1897) Art. IV, § 30; III. (1870) Art. VI, \$ 21; Ind. (1851) Art. VII, \$ 14; Kan. (1859) Art. III, § 9: Ky. (1891) \$\$ 109, 142; Md. (1867) Art. IV, Part VI, \$ 42; Mo. (1875) Art. VI, § 37 ; N. J. (1844) as amended (1875) and (1897) Art. VI, § 1; Olela. (1906) Art. VII, \& 18; Ore. (1857) Art. VII, \& 1; Pa. (1873) Art. V, \& 11, Árt. III; § 7; R. I. (1842) Art. X, § 7; Tenn. (1870) Art. VI, \& 8; Va. (1902) Art. VI, \$\$ 87, 108; Wash. (1889) Art. IV, § 10; Wis. (1848) Art. VII, \& 15. Constitutional provisions creating the office of justice of the peace but making no provision for jurisdiction should be placed in Class $(Z)$ it seems. In the following constitutions I find no mention of such jurisdiction; $M$. (1819), Mass. (1870), N. Y. (1917), Ohio (1851), Vt. (1793). See Wales v. Belcher (1827) 3 Pick. (Mass.) 508.

Some of the citations in $(X)$ and $(Y)$ above should be in $(Z)$ as to criminal jurisdiction but this will make no difference for our discussion here. Types of these constitutional provisions according to the above classification are here given verbatim:

CLASS A. "The judicial power of the state shall be vested in a Supreme Court, Circuit Courts, Criminal Courts, County Courts, County Judges and Justices of the Peace." Fla. Const. (1885) Art. V, \& 1 .

CLASS B. "The judicial power of the state shall be vested in the senate, sitting as a court of impeachment, in a supreme court, district courts of appeals, superior courts and such inferior courts as the legislature may establish in any incorporated city or town, township, county or city and county." Cal. Const. (1879) as amended (1911) Art. VI, § 1.

CLASS C. "The judicial power of the state shall be vested in a Supreme Court of Errors, a Superior Court and such inferior courts as the General Assembly shall, from time to time, ordain and establish. 
This classification at once suggests that there are two possible methods through which the justice of the peace system may be abolished throughout the state: first, by the adoption of a new constitution or constitutional amendment, or second, by legislative enactment.

The first can give no difficulty. As a sovereign power the state can create, organize and control its own judiciary. Therefore, it can abolish the justice of the peace system throughout its territorial extent and substitute such other courts in its stead or indeed, it need not substitute such other courts but may create and organize a completely new judicial organization. ${ }^{68}$ Furthermore the state by constitution or constitutional amendment may delegate this power to abolish the justice of the peace system to the legislature. ${ }^{69}$ Likewise, it appears that the state may abolish the system as such or it may do so partially. It may, for instance, take away completely all civil and criminal jurisdiction of the justice, thus virtually abolishing the office, yet permitting it to remain such only in name with certain administrative duties to be performed by the justices. ${ }^{70}$

A more difficult problem presents itself, namely, what power has the legislature to abolish completely or partially the justice of the peace system in the state. If the constitution expressly empowers the legislature to abolish the office, no doubt it may exercise that authority. ${ }^{71}$ If the constitution provides that the judicial power of the state shall be vested in the justice of the peace as one of

There shall be appointed in each county a sufficient number of justices of the peace, with such jurisdiction in civil and criminal cases as the General Assembly may prescribe." Conn. Const. (1818) Art. V, $\$ \$ 1,2$.

CLASS D. "The legislative assembly shall have power to abolish the office of justice of the peace and confer that jurisdiction upon the judges of county courts or elsewhere." N. D. Const. (1889) Art. I, § 112.

CLASS X. "Justices of the peace ... shall have jurisdiction in all civil cases where the amount in controversy does not exceed one hundred dollars, except in cases of libel, slander, assault and battery and ejectment." Ala. Const. (1901) Art. VI, $\$ 168$.

CLASS Y. "Justices of the peace shall have such jurisdiction as may be conferred by law, but they shall not have jurisdiction of any cause wherein the value of the property or the amount in controversy exceeds the sum of one hundred dollars, or where the boundaries or title to real property shall be called in question." S. D. Const. (1889) Art. V, \$ 22.

CLASS Z. "Two justices of the peace shall be elected in each townsbip, whose term of office shall be two years, and whose powers and duties shall be prescribed by law." Kan. Const. (1859) Art. III, \$ 9.

08 See People v. Hill (1896) 163 Ill. 186, 46 N. E. 796.

09 City of Chicago v. Reeves, supra, n. 63.

70 See In re Greer (1897) $58 \mathrm{Kan}$. 268, $48 \mathrm{Pac}$. 950. If the legislature has power to do this, then a fortiori the state by constitutional enactment may do so. See also, infra, ns. $88,89$.

71 See Class D, n. 66 supra; City of :Shreveport v. Maroum (1914) 134 La. 490,64 So. 388 . 
the courts of the state, it is equally clear that the legislature is without authority to abolish it. ${ }^{72}$ It has likewise been so held if the constitution provides for the vesting of judicial power in superior and inferior courts generally and in addition thereto provides that a cornpetent number of justices of the peace shall be elected or appointed. ${ }^{73}$ If a constitutional amendment provides for the vesting of judicial power in certain superior courts and in inferior courts which the legislature may from time to time establish, and the justice of the peace is omitted eo nomine from the original section amended, it would seem to evince an intention on the part of the framers of the amendment to give the legislature power to abolish the office of justice of the peace. ${ }^{74}$

Generally, then we would say that in those states having constitutional provisions described as classes $B$ and $D$ the legislature has power to abolish the justice of the peace courts throughout the state and to substitute other courts therefor. In those states having such constitutional provisions described as classes $A$ and $C$ the legislatures have no such power and the only method of abolishing the system in those states is either by constitutional provision directly or by constitutional provision empowering the legislature to abolish the office together with legislative enactment in conformity with such power. ${ }^{75}$

Other constitutional provisions which must be considered in this connection relate to the power conferred on the legislature to fix the jurisdiction to be exercised by the justices of the peace. Under some of these provisions legislatures have attempted in limited districts to abolish the office in effect by reducing the jurisdiction to such an extent that the justices scarcely remained judicial officers. In many states the constitution expressly states the jurisdiction which the justices of the peace shall exercise, leaving the legislatures no power. whatever to deal with the matter. ${ }^{76}$ Under such provisions

72 Gratopp v. Van Eps (1897) 113 Mich. 590,71 N. W. 1080.

73 People v. Howland (1898) 155 N. Y. 270,49 N. E. 775 . "Justices of the peace are constitutional officers; . . . The constitutions of 1777, 1821 and 1846 recognized justices of the peace as a branch of the judiciary; insomuch that it has not been within the powers of legislation to abolish the office." People v. Keller. (1857) 25 Barb. (N. Y.) 421, 422.

Contra: Younker v. Susong (1916) 173 Ia. 663, 156 N. W. 24.

Siee Class C, supra, n. 72.

71 Courtright Pub. Co. v. Bray (1920) 67 Colo. 588, 189 Pac. 30, 31 ; see also Cal. Const. (1879) Art. VI, \$§ 1, 11, as amended (1911); also compare Ohio Const. (1851) Art. IV with same article as amended (1912). See op. cit. supra, n. 65.

70 See classes referred to supra, ns, 66, 67.

70 See supra, n. 67, Class (X). 
the legislature certainly has no authority either to enhance or to decrease such jurisdiction. ${ }^{77}$ In other states the constitutions provide that the legislature may determine the jurisdiction of the justices' courts but state a maximum jurisdiction beyond which the legislature has no authority to confer judicial power. ${ }^{78}$ Other state constitutions provide simply that the legislature may fix the powers and duties of the justice of the peace. ${ }^{79}$ No restriction is placed on such authority..$^{80}$ So far as our discussion here is concerned the problem presented by these last two classes of constitutional provisions is the same. ${ }^{81}$ It is this, how far may the legislature reduce the jurisdiction of the justice of the peace? No one would contend that it cannot reduce such jurisdiction substantially. But can it so far reduce such jurisdiction that it will in effect abrogate the powers and duties of the justice as a judicial officer? On this question there is a conflict of authority. Some courts hold that the "jurisdiction of the justice of the peace, . . . may be placed at a nominal sum or be made of a nominal character," ${ }^{82}$ and that the legislature may limit the powers and duties of the justice to such an extent that "but little more remains of the office than the name."

Other courts hold that such action on the part of the legislature is "arbitrary and unreasonable" and "in violation of the plainest implications of the constitutional provisions" pertaining to the office of justice of the peace, and that it is an attempt on the part of the legislature to do indirectly what it cannot do directly." 84

77 When the constitution deals with this subject exhaustively the legislature has no power to alter the jurisdiction conferred on justices of the peace. The Western Union Tel. Co. v. Taylor (1888) 84 Ga. 408, 413, 11 S. E. 396.

"A justice of the peace is a constitutional officer. . . The legislature cannot deprive constitutional officers of the powers and duties conferred upon them by the constitution." Gratopp v. Van Eps, 113 Mich. 590, 591.

${ }^{78}$ See n. 67, Class (Y).

79 See n. 67, Class (Z).

80 The question of legislative power to pass general or special laws wili not be taken up here, but see Love v. Liddle (1903) 26 Utah, 62, 72 Pac. 185. 81 See Minn. Const. (1857) Art. VI, \$ 8 and Burke v. St. Paul, Minneapolis and Manitoba Ry. Co. (1886) 35 Minn. 172, 28 N. W. 190.

82 In re Greer (1897) $58 \mathrm{Kan} .268,273,48 \mathrm{Pac}$. 950. In this case the court was considering the constitutionality of a statute establishing a city court in Kansas City and which deprived the justices of the peace in the township of all criminal jurisdiction and of all civil jurisdiction except in actions "for the recovery of money only where the amount claimed exclusive of costs does not exceed the sum of one dollar."

83 In re Greer, supra, n. 82. See also Detroit Lumber Co. v. Auxiliary Yacht "Petrel" (1908) 153 Mich. 528, 117 N. W. 80; Levin v. Hewes (1912) 118 Md. 624, 86 Atl. 233; Burke v. St. Paul, Minneapolis \& Manitoba Ry. Co. (1886) 35 Minn. 172, 28 N. W. 190; State v. Cleveland (1918) 164 Wis. 189, 159 N. W. 837; State v. Burke (1915) 161 Wis. 429,54 N. W. 627.

84 State ex rel. Burke v. Hinkel (1911) 144 Wis. 444, 129 N. W. 393. In this case the court was considering a statute which provided that in munici- 
In solving the problem of state-wide abolition of the office of justice of the peace then, it seems that the only certain method of eradicating this anachronism from our jurisdiction is by constitutional provision or amendment abolishing it directly or by such provision or amendment authorizing the legislature to abolish it followed by a legislative enactment in conformity with such provision. ${ }^{86}$

\section{SUMMARY}

While the justice of the peace system has a long history and has been firmly imbedded in the fundamental laws of the states, yet it is an anachronism in our jurisprudence the perpetuation of which cannot be justified. The justices of the peace as a class are wholly unqualified for the positions they occupy. The pernicious fee system and local politics break down their integrity and lead to corruption. They are often ignorant and wholly uncontrolled by statute or constitution. Their decisions are purely personal. The administration of justice by these lay magistrates is uncertain, unequal and unstable, and in. truth, the system as such, is a denial of justice according to our highest conception of that term.

The importance of the justice of the peace system cannot be

palities in counties of 150,000 inhabitants or over, and in cities of the first class, the justices of the peace should thereafter have jurisdiction only in actions when the amount claimed or involved did not exceed the sum of one dollar. The statute also provided that the justice should receive a salary of twenty-five dollars annually in lieu of all fees, that such justices' court should be open for business at least six hours each day of the year, Sundays and holidays excepted, and that the justice was to have a four-weeks vacation.

See also Taylor v, Woods (1875) 52 Ala. 474; Pearce v. Pope (1868) 42 Ala. 319; Averill v. Perrott (1889) 74 Mich. 296, 41 N. W. 929 ; People v. Howland (1898) 155 N. Y. 270,49 N. E. 775.

The problem submitted as a state-wide matter does not appear to have been before our courts and we are not at liberty here to do more than point out the difficulties to be encountered. The cases examined have generally come hefore the courts on the question of legislative power to reduce the justices' jurisdiction or abolish the office as such in a particular city or district. No attempt has been made at this time to examine all cases on the subject.

85 See City of Shreveport v. Maroun (1914) 134 La. 490, 64 So. 388.

Perhaps therc are other courts which would take the position of the Iowa court in Younker v. Susong, supra, n. 73, and hold that even though the justice of the peace is provided for in its constitution, it is nevertlieless, a statutory office. At page 669 this court said: "Justices of the peace and their ofice, not being of constitutional creation, may be established or abolished at the will of the legislature."

While this decision hardly appears to be a sound doctrine as a matter of constitutional law, yet it would materially simplify and minimize the problem of abolishing the justicc of the peace system in the states if the courts so held. 
over-estimated for it is in these minor courts that most of our citizens come in contact with our judicial organization. Here it is that our courts have their greatest political influence. Here it is that confidence or lack of it is established in our judiciary.

In recent statutes and constitutions there is a tendency to improve the justice of the peace courts and to abolish them in urban districts and great metropolitan centers. But little has been accomplished bringing relief to the great mass of our people. This is a discrimination against litigants in rural communities who are still compelled to submit their controversies to the traditional justice.

If our states are to realize the ideal of the Magna Charta, that "To no one will we sell, to no one will we refuse or delay, right or justice," there must be state-wide abolition of the office of justice of the peace. This can be accomplished most certainly and effectively by constitutional enactment.

Chester H. Smith.

Tulane University College of Law, New Orleans, Louisiana.*

\#This article was written while the author was at the University of Montana, Missoula, Montana. 